\title{
Analysis of action plans and coping plans for reducing salt consumption among women with hypertension ${ }^{1}$
}

\author{
Rúbia de Freitas Agondi² \\ Maria Cecília Bueno Jayme Gallani ${ }^{3}$ \\ Marilia Estevam Cornélio² \\ Roberta Cunha Matheus Rodrigues ${ }^{3}$
}

\begin{abstract}
This cross-sectional study, based in implementation intention theory, describes action plans developed by women with hypertension $(n=49)$ to add no more than $4 \mathrm{~g}$ of salt per day to food and to reduce consumption of salty foods, as well as describing the barriers perceived and the coping strategies adopted for putting the action plans into practice. The plans were categorized according to similarities and were submitted to frequency analysis. The majority of the action and coping plans had to do with the effectuation of the behavior involving adding up to $4 \mathrm{~g}$ of salt per day per person to food. The action strategies were aimed at quantifying the salt added, and the main obstacles were related to the reduced palatability of the food made with less salt. The coping plans have to do with preparing foods separately and to using natural seasonings instead of salt. This data can help the nurse to design activities for clinical education, with a view to reducing salt consumption among patients who prepare their own food.
\end{abstract}

Descriptors: Hypertension; Sodium Chloride, Dietary; Feeding Behavior.

\footnotetext{
${ }^{1}$ Paper extracted from Master's Dissertation "Efeito das estratégias de Planejamento da Ação e Enfrentamento de Obstáculos sobre a redução do consumo de sal entre mulheres hipertensas - um estudo piloto", presented to Departamento de Enfermagem, Faculdade de Ciências Médicas, Universidade Estadual de Campinas, Brazil. Supported by Coordenação de Aperfeiçoamento de Pessoal de Nível Superior (CAPES).

2 Doctoral Students, Departamento de Enfermagem, Faculdade de Ciências Médicas, Universidade Estadual de Campinas, Brazil.

${ }^{3}$ PhD, Associate Professor, Departamento de Enfermagem, Faculdade de Ciências Médicas, Universidade Estadual de Campinas, Brazil.
} 
Análise dos planos de ação e planos de enfrentamento de obstáculos para a redução do consumo de sal entre mulheres com hipertensão arterial sistêmica

Este é um estudo transversal, baseado na teoria Implementation Intentions, cujo objetivo foi descrever planos de ação desenvolvidos por mulheres hipertensas $(n=49)$ para adicionar, no máximo, $4 \mathrm{~g}$ de sal/dia aos alimentos e reduzir o consumo de alimentos salgados, bem como barreiras percebidas e estratégias de enfrentamento para efetivar os planos de ação. Os planos foram categorizados quanto à similaridade e submetidos à análise de frequência. A maioria dos planos de ação e enfrentamento de obstáculos referiu-se à efetivação do comportamento para adicionar, no máximo, 4g/sal/dia/pessoa aos alimentos. As estratégias de ação foram voltadas para a quantificação do sal adicionado, e os principais obstáculos foram relacionados à menor palatabilidade dos alimentos com menos sal. Os planos de enfrentamento apontaram para o preparo, em separado, dos alimentos e uso de temperos naturais em substituição ao sal. Esses dados podem auxiliar o enfermeiro para direcionar atividades clinicoeducativas, visando a redução de consumo de sal entre pacientes que preparam sua alimentação.

Descritores: Hipertensão; Cloreto de Sódio na Dieta; Comportamento Alimentar.

\title{
Análisis de los planes de acción y planes para hacer frente a los obstáculos a la reducción de la ingesta de sal en las mujeres hipertensas
}

\begin{abstract}
Este estudio transversal, basado en la teoría Implementation Intentions, describe los planes de acción desarrollados por las mujeres hipertensas $(n=49)$ para añadir hasta $4 \mathrm{~g}$ de sal/ día a los alimentos y comer menos alimentos salados, así como las barreras percibidas y estrategias de afrontamiento para llevar a cabo los planes de acción. Los planes fueron agrupados como la similitud y la sometieron a un análisis de frecuencia. La mayor parte de los planes se refiere a la eficacia de la conducta de añadir a los alimentos $4 \mathrm{~g} / \mathrm{sal} / \mathrm{día} /$ persona. Los planos de acción estaban dirigidos a la cuantificación de la sal y los principales obstáculos estaban relacionados con disminución de la palatabilidad de los alimentos bajos en sal. Estrategias de afrontamiento fueron dirigidos a preparar la comida por separado y en uso de especias naturales. Estos datos pueden ayudar a la enfermera en la dirección de las actividades clínicas y educativas.
\end{abstract}

Descriptores: Hipertensión; Cloruro de Sodio Dietético; Conducta Alimentaria.

\section{Introduction}

Arterial hypertension $(\mathrm{AH})$ is a condition with multiple causes, with high sodium consumption being a key factor in the greater pressure levels found in hypertensives compared to normotensives ${ }^{(1)}$. Studies - experimental, populational and systematic review - have shown a direct relation between reduction in consumption of sodium in food and decrease in arterial pressure (AP) levels and, consequently, in cardiovascular risk resulting from hypertensive scenarios ${ }^{(2-4)}$.

The restriction of salt in the diet is an important nonpharmacological measure for the therapeutic management of the hypertensive patient, a maximum consumption of $4 \mathrm{~g}$ of salt per day or $1600 \mathrm{mg}$ of sodium per day being recommended for these individuals ${ }^{(5)}$. Recent studies, however, provide evidence of daily salt consumption among hypertensives of around 12.5 to $13 \mathrm{~g}$, mainly originating from salt added during the preparation of foods ${ }^{(6-7)}$.

The development of interventions for reducing the addition of salt during food preparation in this population is thus a priority. The form of the intervention, however, depends on establishing the determinant factors behind the adoption or not of this behavior.

A previous study ${ }^{(7)}$ for identifying predictive factors for salt consumption among hypertensives, carried out using an expanded version of the theory of planned behavior (TPB) ${ }^{(8)}$, found that the principal predictor for the behavior of adding salt to foods was intention. However, although it reproduced the prerequisite of the cognitive-behavioral models according to which motivation to act (intention) is the principal determinant for action (behavior) ${ }^{(8-10)}$, it was noted that the 
intention only explained $22 \%$ of its variability. Such a result characterizes what in the literature has been termed a 'gap' in the intention-behavior relationship, presenting principally in individuals who possess a positive intention to adopt the behaviour, but who fail to implement it(11).

The strategy called Implementation intentions aims to help individuals to turn positive intentions into effective behavior. This strategy has been divided by some authors into two components: Action Planning ${ }^{(12)}$ and Coping Planning(13). Action Planning consists of mental simulation, linking situational cues and concrete behavioral responses to future situations, specifying when, how and where a determined action will take place. Action planning is seen as a tool for the development of self-regulatory habits to help in behavioral change, making individuals aware of matching future situations of accomplishing the behavior with possible coping responses(12).

Coping Planning is focussed on risk situations or barriers which may impede or negatively interfere with the achievement of a target behavior ${ }^{(13)}$. It is independent cognitive planning and represents a mental link between the anticipation of situations which will put the achievement of the planned behavior at risk and possible coping responses. This planning aims to empower the individual to act in accordance with his or her intentions even in situations in which the barriers or obstacles change the intended action or when counterintentional behaviors are evoked ${ }^{(14)}$.

To our knowledge, at the time of writing no study has applied the implementation intentions strategy to salt consumption reduction. The identification of how hypertensive patients imagine it to be possible to reduce sodium consumption, as well as of possible barriers anticipated and the strategies identified to overcome them, provides support for the activities of the nurse who would like to implement intervention with a view to reducing sodium consumption in other populations too. Thus, this study aims to describe the action plans developed by these women for adding a maximum of $4 \mathrm{~g}$ of salt per day to foods and for reducing their consumption of highly-salted foods, as well as the barriers perceived and the respective coping strategies hypothesized such that the action plans may be carried out.

\section{Method}

This study is a cross-section of a wider experimental study ${ }^{(15)}$, which verified the effect which the action planning and coping planning interventions had on the reduction in salt consumption among hypertensive women. In this study, the planning elaborated by the hypertensive women was subjected to descriptive-exploratory analysis. The study was undertaken in three outpatient centers specialized in care for hypertensive patients and a primary healthcare unit in Campinas, Brazil. The subjects of the study were 49 hypertensive women included in the intervention group of the experimental study(15); the criteria for inclusion in the group were to be over 18 years of age, to have been clinically followed for over six months, and to be responsible for making their own meals. The participants were characterized by sociodemographic variables (age, ethnicity, years of schooling completed, marital status, whether or not they are working legally, and their individual and family monthly income, as determined by a previously validated instrument ${ }^{(6-7)}$ ) and by clinical variables (arterial pressure ${ }^{(16)}$ and body mass index obtained by a physical exam at the time of the interview). The characterization of salt consumption was carried out through two self-reporting instruments validated in previous studies ${ }^{(6-7)}$ (salt consumption per capita and a questionnaire evaluating consumption of ready-made seasonings) and urinary excretion of sodium over 24 hours, obtained by atomic absorption spectrometry analysis of a sample of urine from the 24 hour period.

\section{Planning Strategies}

The planning strategies were arranged in individual sessions, one week after the individual's inclusion in the study, with the use of the following forms:

Action Planning: a form in which the participant in the research would note, with the researcher's help, up to three action plans, about when, where and how she would reduce the addition of salt in preparing foods over the following two months. The form started with the instruction: Think about your daily food in the next two months. When, where and how are you planning to reduce the addition of salt to the food? Together, let's write your plans in the table which I'm going to show you. Remember that the more precise and realistic you are in defining your plans, and the more you come up with your plans on your own, the greater your chances will be of putting them into action. The form ends with the following information: Memorize your plans carefully. Visualize the situations and what you have planned. Try to keep strongly committed so that you act as you have planned.

Coping Planning: a form in which the participant notes, with or without the health professional's help, up to three possible obstacles to reducing salt consumption and the respective strategies for overcoming them. The form begins with the instruction: Think about the obstacles or barriers which might interfere with your reduction in salt intake. How could you overcome these obstacles or barriers? Together, let's write your plans in the table which I'm going to show you. Once again, remember that the more you're precise and realistic in defining your plans, and the more you come up with your plans on your own, the better your chances are 
of putting them into action. The form ends with the following advice: Visualize the situations and your plans for confronting the obstacles and try to keep strongly committed, so that you act as you have planned.

The plans were developed in duplicate, one in the possession of the researcher and the other in the possession of the participant, who was advised to keep it visible and check it whenever she had doubts. The individuals were encouraged to develop their plans for effectuation of the behavior of adding up to $4 \mathrm{~g}$ of salt per day in the preparation of foods and reducing consumption of highly-salted foods. When necessary, the researcher helped with devising the plans.

\section{Data analysis and Ethical Aspects}

The analysis of the plans developed was set up following recommendations for content analysis in the context of behavioural study theories ${ }^{(17-18)}$. Three lists were composed: one for the action plans, one for the obstacles anticipated, and one for the coping plans. The plans, like the obstacles, were grouped according to similarities in each of the domains researched, making it possible to determine their frequency. Each one of the items was numbered, according to the questionnaire of origin, making it possible to identify the context and carry out future cross-referencing of information. In all the lists, the plans and obstacles were separated according to the desired behavior (to reduce the addition of salt to foods or to reduce the consumption of highly-salted foods). Two researchers independently carried out the analysis and categorization of the data. The data was subjected to descriptive analysis (averages, standard deviation, medians for the continuous variables and of frequency for the categorical variables). The study was approved by the local Research Ethics Committee (report 259/2009). All the participants in the research signed the terms of Free and Informed Consent and received a copy.

\section{Results}

\section{Characterization - Clinical, Sociodemographic and by Salt Consumption}

Table 1 describes the sociodemographic and clinical characteristics, and the salt consumption, of the patients in

Table 1 - Characteristics - sociodemographic, clinical, and by salt consumption $(n=49)$, Campinas, São Paulo State, Brazil, 2010/2011

\begin{tabular}{|c|c|c|c|}
\hline & $\mathrm{N}$ & $\%$ & \\
\hline \multicolumn{4}{|l|}{ Institution } \\
\hline Outpatient & 29 & 59.2 & \\
\hline Primary Healthcare Unit & 20 & 40.8 & \\
\hline \multicolumn{4}{|l|}{ Ethnicity } \\
\hline Caucasians & 25 & 51.0 & \\
\hline Non-caucasians & 24 & 48.9 & \\
\hline \multicolumn{4}{|l|}{ Marital Status } \\
\hline Single & 21 & 42.9 & \\
\hline Has significant other & 28 & 57.1 & \\
\hline \multicolumn{4}{|l|}{ Occupation } \\
\hline Active & 8 & 16.3 & \\
\hline Inactive & 21 & 42.7 & \\
\hline \multirow[t]{2}{*}{ Housewife } & 20 & 40.8 & \\
\hline & Average (sd) & Average (IQR) & Variance \\
\hline Age & $59.4(8.0)$ & $59.0(12.0)$ & $37-78$ \\
\hline Schooling & $4.0(3.0)$ & $4.0(3.0)$ & $0-13$ \\
\hline Individual income* & $1.0(0.8)$ & $1.0(1.5)$ & $0-3.3$ \\
\hline Family income* & $2.4(1.8)$ & $2.0(1.9)$ & $0-7.5$ \\
\hline Average arterial pressure & $105.4(16.1)$ & $103.7(17.3)$ & $75.3-158.3$ \\
\hline Body Mass Index & $31.7(6.2)$ & $31.7(8.2)$ & $19.1-49.5$ \\
\hline Salt consumption, per capita ${ }^{\dagger}$ & $6.7(4.8)$ & $5.3(6.7)$ & $2.0-26.7$ \\
\hline Consumption of ready-made seasonings ${ }^{\ddagger}$ & $0.6(0.8)$ & $0.2(0.8)$ & $0-3.2$ \\
\hline Total salt consumption ${ }^{\dagger}$ & $7.3(4.9)$ & $5.7(7.3)$ & $2.2-26.7$ \\
\hline Urinary Sodium & $171.2(70.1)$ & $156.2(95.7)$ & $56.0-384.8$ \\
\hline Salt consumption, estimated by Urinary Sodium ${ }^{\dagger}$ & $9.9(4.1)$ & $9.1(5.5)$ & $3.2-22.3$ \\
\hline
\end{tabular}

*in Brazilian minimum salaries (MS) (1 MS = R \$510.00); ${ }^{\dagger}$ in grams; ${ }^{*}$ salt consumption resulting from use of ready-made seasonings, in grams; sd: standard deviation; IQR: inter quartile range. 
the study. The sample was mainly made up of married women, either professionally inactive or housewives, obese, with little schooling and low monthly income. Salt consumption, estimated by urinary excretion of sodium, was at least twice as high as recommended for those with arterial hypertension.

\section{Action Planning and Coping Planning}

On average, $2.5( \pm 0.6)$ action plans and $1.6( \pm 0.91)$ coping plans were developed for each participant in the research. Table 2 describes the action plans, obstacles perceived and coping plans for adding up to $4 \mathrm{~g}$ of salt per day per person to foods. The most frequently-found action plans referred to using or separating a teaspoon of salt per person per day for adding to food (97.9\%) and separating a teaspoon for using to measure the salt to be added to foods (51.0\%).

The obstacles mentioned with equivalent frequency were: complaints from the family in relation to the taste of food $(36.4 \%)$, the presence of visitors coming for meals

Table 2 - Description of action plans, obstacles and coping strategies for the behavior of adding up to one teaspoon of salt per person per day in the preparation of foods, Campinas, São Paulo State, Brazil, 2010/2011

\begin{tabular}{|c|c|}
\hline & n (\%) \\
\hline \multicolumn{2}{|l|}{ Action Plans $(n=49)$} \\
\hline 1.Use/separate one teaspoon of salt per person per day to add to foods & $48(97.9)$ \\
\hline 2.Separate a teaspoon to be used as a measure for the salt to be added to the foods & $25(51.0)$ \\
\hline 3. Stop adding salt to specific preparations, such as rice, salads and vegetables. & $9(18.4)$ \\
\hline 4. Use only measured salt to add to the foods & $2(4.1)$ \\
\hline 5. Don't use salt when preparing home-made seasoning & $1(2.0)$ \\
\hline 6. Substitute some salty meals during the week with milkshakes or fruit juices & $1(2.0)$ \\
\hline 7.Add natural seasonings to foods instead of salt or ready-made seasonings & $1(2.0)$ \\
\hline \multicolumn{2}{|l|}{ Obstacles Perceived $(n=44)$} \\
\hline 1.Complaints from the family about the foods' flavor & $16(36.4)$ \\
\hline 2.Presence of visitors for meals at home & $16(36.4)$ \\
\hline 3. Reduced palatability of foods & $15(34.0)$ \\
\hline 4. Other members of the family who cook adding more salt than recommended during food preparation & $1(2.3)$ \\
\hline 5.Belief that one's own arterial pressure or that of a family member will reduce too much & $1(2.3)$ \\
\hline \multicolumn{2}{|l|}{ Coping Strategies $(n=44)$} \\
\hline 1.Use natural seasonings instead of adding salt or ready-made seasonings & $12(27.3)$ \\
\hline 2. Prepare one's own food separately from that of family members or visitors & $11(25.0)$ \\
\hline 3. Prepare food with the appropriate amount of salt and request family members or visitors to add salt to their own meals. & $10(22.7)$ \\
\hline 4. Reinforce with one's family and remember the importance of reducing salt consumption for individual and collective health & $5(11.3)$ \\
\hline 5.Season one's own food separately from food for family members and visitors & $4(9.0)$ \\
\hline 6. Within the limit, add more salt to certain foods (principally meat) and less for others (principally salads) & $3(6.8)$ \\
\hline 7. Ask family members to prepare food with the appropriate amount of salt & $3(6.8)$ \\
\hline 8. Use only the salt measured out for the day in preparing meals & $2(4.5)$ \\
\hline 9. Progressively reduce the quantity of salt added to food & $1(2.3)$ \\
\hline
\end{tabular}

Table 3 - Description of action plans, obstacles and coping strategies identified for the behavior of avoiding the consumption of highly-salted foods and ready-made seasonings, Campinas, São Paulo State, Brazil, 2010/2011)

\begin{tabular}{|c|c|}
\hline & n (\%) \\
\hline \multicolumn{2}{|l|}{ Action Plans $(n=49)$} \\
\hline 8. Stop buying, or reduce frequency of consumption/portion size of, ready-made seasonings & $32(65.3)$ \\
\hline 9.Stop consuming, or reduce frequency of consumption/portion size of, highly-salted foods & $4(8.2)$ \\
\hline 10.Stop buying pre-seasoned ready-meals at the supermarket & $1(2.0)$ \\
\hline \multicolumn{2}{|l|}{ Obstacles Perceived $(n=44)$} \\
\hline 6. Eating out (in restaurants and, principally, at relatives') or having food delivered & $23(52.3)$ \\
\hline 7.Eating foods which are intrinsically highly salted & $7(15.9)$ \\
\hline \multicolumn{2}{|l|}{ Coping Strategies $(n=44)$} \\
\hline 10. When eating out, to serve oneself more with unseasoned foods (salads and vegetables cooked without salt) & $16(36.4)$ \\
\hline 11. Stop consuming highly-salted foods or eat them less frequently or in smaller quantities & $7(15.9)$ \\
\hline 12.Substitute preparations high in salt for meals which contain less of this nutrient & $3(6.8)$ \\
\hline 13.Stop eating in restaurants, snack-bars or relatives' houses & $2(4.5)$ \\
\hline
\end{tabular}


at home $(36.4 \%)$ and the reduced palatability of the food $(34.0 \%)$. The coping plans developed to overcome the obstacles were: substitution of salt and ready-made seasonings with natural seasonings $(27.3 \%)$, preparing foods for one's own consumption separately (25.0\%) and requesting family members and visitors to add salt to their meals after preparation (22.7\%).

For the behavior of reducing consumption of highlysalted foods and ready-made seasoning, the most frequent action plan was to stop buying or to reduce the frequency of use of, or portion size of, ready-made seasonings (65.3\%). The obstacle referred to most (52.3\%) was eating out (in restaurants or in relatives' houses) which makes it difficult to control the quantity of salt added to the food. As far as coping plans are concerned, the most frequent was to serve oneself with unseasoned foods (salads, vegetables cooked without salt) when not dining at home (36.4\%).

Figure 1 presents the association between action plans, perceived obstacles and coping strategies.

\section{Discussion}

It was observed that average salt consumption in the group studied (estimated by urinary sodium) was more than twice what is recommended in the literature for those with arterial hypertension(5), related principally to the addition of salt in the preparation of foods, corroborating the findings of previous studies(6-7), and confirming the need for the development of interventions focussed on this behavior.

\begin{tabular}{|c|c|c|}
\hline Action Plan & Obstacle & Coping Strategy \\
\hline \multirow{19}{*}{$\begin{array}{l}\text { Use one teaspoon of salt per } \\
\text { person per day in foods }\end{array}$} & \multirow{3}{*}{$\begin{array}{l}\text { Finding the taste of the foods } \\
\text { strange }\end{array}$} & Reinforce that eating little salt is important for health \\
\hline & & Use natural seasonings \\
\hline & & Add salt more to some preparations than others, within the limits. \\
\hline & \multirow{5}{*}{$\begin{array}{l}\text { Family complaints in relation to the } \\
\text { flavor of foods }\end{array}$} & Season specific preparations with more salt for family members \\
\hline & & Request family members to add salt to their meals \\
\hline & & Progressively reduce the quantity of salt in foods \\
\hline & & Reinforce that eating little salt is important for health \\
\hline & & Cook one's own food separately \\
\hline & \multirow{5}{*}{ Eating out or at relatives' } & Stop eating out \\
\hline & & When eating out, to serve oneself more with unseasoned foods \\
\hline & & Stop eating heavily-salted foods \\
\hline & & Request family members to add the appropriate amount of salt. \\
\hline & & $\begin{array}{l}\text { Substitute the consumption of foods rich in salt with others containing less of } \\
\text { this nutrient }\end{array}$ \\
\hline & \multirow{4}{*}{ The presence of visitors at home } & Cook one's own food separately from that of visitors \\
\hline & & Request visitors to add salt to their meals \\
\hline & & Season preparations specifically for visitors separately \\
\hline & & Use only the salt measured out in the preparation of the foods \\
\hline & Other members of the family cook & $\begin{array}{l}\text { Request that members of the family add to the foods only the appropriate } \\
\text { quantity of salt for the day }\end{array}$ \\
\hline & $\begin{array}{l}\text { A belief in the family that arterial } \\
\text { pressure can drop too far }\end{array}$ & Request to family members that they add salt when they eat \\
\hline \multirow{3}{*}{$\begin{array}{l}\text { Stop using ready-made } \\
\text { seasonings }\end{array}$} & Finding the flavor strange & Use natural seasonings \\
\hline & Other members of the family cook & $\begin{array}{l}\text { Request that members of the family add to the foods only the appropriate } \\
\text { quantity of salt for the day }\end{array}$ \\
\hline & $\begin{array}{l}\text { Complaints from the family about the } \\
\text { taste of the foods }\end{array}$ & Request family members to add salt when they eat \\
\hline \multirow[b]{2}{*}{ Stop eating highly-salted foods } & Eating out & When out, serve oneself more with unseasoned foods \\
\hline & $\begin{array}{l}\text { Consumption of foods with high salt } \\
\text { levels }\end{array}$ & $\begin{array}{l}\text { Stop eating highly-salted foods or eat them less frequently or in smaller } \\
\text { quantities }\end{array}$ \\
\hline $\begin{array}{l}\text { Substitute salty meals with } \\
\text { milkshakes or fruit juices }\end{array}$ & Eating out & When out, serve oneself more with unseasoned foods \\
\hline \multirow{4}{*}{$\begin{array}{l}\text { Stop adding salt to specific } \\
\text { preparations }\end{array}$} & \multirow{2}{*}{$\begin{array}{l}\text { Complaints from the family about the } \\
\text { taste of the foods }\end{array}$} & Season specific preparations for the family separately \\
\hline & & Reinforce that eating little salt is important for health \\
\hline & Finding the taste strange & Use natural seasoning \\
\hline & The presence of visitors at home & Use only the salt measured out for the day \\
\hline
\end{tabular}

Figure 1 - Association between Action Plans, Obstacles and Coping Strategies. Campinas, São Paulo, Brazil, 2010/2011 
This study aimed to analyze the action plans, obstacles and coping plans elaborated by hypertensive women to reduce the addition of salt in foods, as well as reduce the consumption of highly-salted foods and ready-made seasonings. Carrying out this planning is a central stage in the Implementation Intentions strategy, which aims to help the individual to implement positive intentions, turning them into effective behavior, serving as a "guide for action"(12-14).

The analysis of the interviews pointed to the diversity of action plans, as well as of the obstacles anticipated and the coping plans, which were coherent with each other and formulated by the patients themselves, independently or with the help of the researcher, as envisaged in the Implementation Intentions strategy.

It can be seen that the patients elaborated many action plans and coping plans for the behavior of using no more than $4 \mathrm{~g}$ of salt in food preparation. As salt added to food is the principal source contributing to total salt consumption in this group, the implementation of these plans should contribute significantly to the reduction in ingestion of this nutrient.

Below, some aspects referent to the most frequent action plans, obstacles and coping plans in the group studied are discussed.

Among the action plans for the effectuation of the behavior of adding at most one teaspoon of salt per person per day to foods, the plan to use a measure for quantifying the salt used on food preparation stands out. A previous study which evaluated the determinants for this behavior among hypertensive women(7) observed that the higher an individual's score for their habit of not controlling salt use, the less motivated they were to adopt the behavior. In the study referred to, the beliefs that obtained the highest scores were: "using more than $4 \mathrm{~g}$ of salt per day in food preparation is: something I do automatically, do frequently and which is part of my routine".

Habit is defined as a sequence of learnt acts which become automatic responses in one's day-to-day, the automaticity and lack of consciousness being the most important elements in characterizing it. In this context, the behavior is guided by implicit structures, without decisions being made(19). Thus, the plans elaborated portray an attempt to modify the automatic character which surrounds the food practice of lack of control in salt addition, and show that they are important for this population.

Among the obstacles to reducing salt consumption referred to, what stands out is families' complaints about the food's flavor, the presence of visitors coming for meals, and reduced palatability of food. Similar results were also observed among patients with cardiac and renal insufficiency ${ }^{(20-21)}$. Considering the strategies for coping with the obstacles, such as adding natural seasonings to food instead of salt, one can observe that the patients themselves seek to circumvent the reduction of pleasure in food caused by reducing salt by substituting it with other seasonings. Through their adoption of practical alternatives to salt, one can observe the importance given by patients to the fact of recognizing and respecting the pleasurable side of eating.

As far as reducing consumption of highly-salted foods is concerned, more than half of the patients referred to eating out as an obstacle. In a study carried out with 246 patients with cardiac insufficiency, approximately half of those interviewed referred to the fact of friends or family members not offering low-salt options at their homes as a barrier(20). However, it was observed that the patients were able to formulate strategies to overcome this difficulty, by, for example, serving themselves more with unseasoned foods.

Another aspect frequently mentioned among obstacles was concern about family members' and visitors' opinions about the taste of foods prepared with less salt. For these obstacles, the coping strategies proposed were: to prepare one's own food separately from that of the rest of the family and visitors, and, further, to ask family members/visitors to add salt to their own food if they wished. The patients also emphasized the importance of reinforcing on the family the need to consume food with less salt, not only for their personal health but for that of the family too.

It may be seen that the action plan which presented the most obstacles related to its implementation was the plan referring to using one teaspoon of salt per person per day in food preparation (which was related with six of the ten obstacles referred to for this behavior). Such a phenomenon suggests that this plan, despite its frequency in the study's population, indicates a behavior which the patients perceive as difficult to implement.

Studies carried out with hypertensive women with cardiac insufficiency ${ }^{(21-22)}$ identified that the lack of educative and counselling activities for salt reduction carried out by a health professional - was perceived as an important barrier to reducing salt ingestion. Remaining with these studies, having a health professional to followup to assist the change in this behavior was indicated as a strategy for coping with the difficulties perceived in reducing salt consumption. The use of the combined strategies of action plans and coping with obstacles can be an effective way to change eating practices related to the ingestion of sodium.

It is supposed that the formulation of an action plan increases an individual's chances of acting as he or she had 
intended and also to initiate the target-behavior faster ${ }^{(12)}$. Specifying when, where and how a determined action will take place permits the reporting of situational cues and concrete behavioral responses to future situations, meaning that spontaneous reactions may be replaced with previously constructed plans(12). Coping planning, in its turn, is focussed on risk situations or barriers that can impede or interfere negatively with the implementation of target-behavior, triggering necessary self-regulating coping responses which are already available to the subject, as a result of her previous experiences ${ }^{(13-14)}$.

As the literature clearly emphasizes ${ }^{(8)}$, providing information alone is not enough to change behavior in health. The emphasis of this study falls on the elements identified in the target-population as important for making reduced salt consumption possible. The patients recognized means of doing this, as well as possible obstacles and how to overcome them. This information is important for the nurse who aims to assist hypertensive women in reducing salt consumption. Future studies, involving a wider clientele, such as hypertensive men and women who are not responsible for preparing their own meals, as well as other behaviors related to salt consumption, may bring important support for widening the scope of clinical-educative nursing interventions.

\section{Conclusions}

It is concluded that action plans and plans for coping with obstacles were, on the whole, coherent, with the measuring of the salt used during or after food preparation standing out as the principal action plan. The most frequent barrier was the loss of palatability of food, perceived by the patient herself or by her social contacts; having as its coping plan the separate preparation of the subject's own food, and use of natural seasonings. This data can help the nurse to direct her clinical-educative activity concerning the reduction of salt consumption among patients who prepare their own food.

\section{References}

1. He FJ, MacGregor GA. Reducing Population Salt Intake Worldwide: From Evidence to Implementation. Prog Cardiovasc Dis. 2010;52:363-82.

2. Altun B, Arici M. Salt and Blood Pressure: Time to Challenge. Cardiology. 2006;105:9-16.

3. Cappuccio FP, Kerry SM, Micah FB, Plange-Rhule J, Eastwood JB. Community programme to reduce salt intake and blood pressure in Ghana. BMC Public Health. 2006;6(13):1-11.
4. Elliott $P$, Walker LL, Little MP, Blair-West JR, Shade RE, Lee $R$, et al. Change in Salt Intake Affects Blood Pressure of Chimpanzees: Implications for Human Populations. Circulation. 2007;116:1563-8.

5. Sociedade Brasileira de Cardiologia, Sociedade Brasileira de Hipertensão, Sociedade Brasileira de Nefrologia. VI Diretrizes Brasileiras de Hipertensão. Arq Bras Cardiol. 2010;95(1 supl 1):1-51.

6. Ferreira-Sae MCS, Gallani MCJB, Nadruz Júnior W, Rodrigues RCM, Franchini KG, Cabral PC, et al. Reliability and validity of a semi-quantitative FFQ for sodium intake in low-income and low-literacy Brazilian hypertensive subjects. Pub Health Nutr. 2009;28:168-73.

7. Cornélio ME, Gallani MCBJ, Godin G, Rodrigues RCM, Mendez RDR, Nadruz W Junior. Development and reliability of an instrument to measure psychosocial determinants of salt consumption among hypertensive patients. Rev. Latino-Am. Enfermagem. 2009;17(5):701-7.

8. Ajzen I. The theory of Planned behavior. Organizational behavior and human Decision processes. Psychol Rev. 1991;50:179-211.

9. Fishbein M, Ajzen I. Understanding attitudes and predicting social behavior. Englewood Cliffs: Prentice Hall; 1980.

10. Ajzen I.The theory of planned behaviour: reactions and reflections. Psychol Health. 2011;26(9):1113-27.

11. Orbell S, Sheeran P. "Inclined abstainers": A problem for predicting health-related behavior. $\mathrm{Br} J$ Soc Psychol. 1998;37:151-65.

12. Gollwitzer PM. Implementation Intentions: Strong Effects of Simple Plans. Am Phychol. 1999;54(7): 493-503.

13. Sniehotta FF, Nagy G, Scholz U, Schwarzer R. Action control during the first weeks of health behavior change: A longitudinal study with $\mathrm{CHD}$ patients. $\mathrm{Br}$ J Soc Psychol. 2004;45:87-106.

14. Sniehotta FF, Schwarzer R; Scholz RSU, Schuz B. Action planning and coping planning for long-term lifestyle change: Theory and assessment. Eur J Soc Psychol. 2005;35:565-76.

15. Agondi RF. Efeito das estratégias de Planejamento da Ação e Enfrentamento de Obstáculos sobre a redução do consumo de sal entre mulheres hipertensas - um estudo piloto [Dissertação de Mestrado]. Campinas (SP): Universidade Estadual de Campinas; 2011.

16. US Department of Health and Human Services. The Seventh Report of the Joint National Committee on Prevention, Detection, Evaluation and Treatment of High Blood Pressure. NIH Publication. 2004. [acesso 14 mar 2009]. Disponível em: http://www.nhlbi.nih.gov/ guidelines/hypertension. 
17. Godin G, Gagné C. Les théories sociales cognitives: guide pour la mesure des variables et le développement de questionnaire. Groupe de recherche sur les aspects psychosociaux de la santé. École des sciences infirmières, Université Laval; 1999. [acesso 22 abr 2011]. Disponível em: http://www.godin.fsi.ulaval.ca/Fichiers/Rapp/Guide_ mesure_variables.pdf.

18. Godin G, Kok G. The theory of planned behavior: a review of its application to health-related behaviors. Am J Health Promotion. 1996;11(2):87-98.

19. Verplanken B, Myrbakk V, Rudi E. The measurement of habit. In: Betsch T, Haberstroh S. The routines of decision making. Mahwah: Lawrence Erlbaum; 2005. p. 231-47.

20. Lennie TA, Worrall-Carter L, Hammash M, OdomForren J, Roser LP, Smith CS, et al. Relationship of Heart Failure Patients' Knowledge, Perceived Barriers, and Attitudes Regarding Low-Sodium Diet Recommendations to Adherence. Prog Cardiovasc Nurs. 2008;23(1):6-11.

21. Brito-Ashurst I, Perry L, Sanders TAB, Thomas JE, Yaqoob MM, Dobbie H. Barriers and facilitators of dietary sodium restriction amongst Bangladeshi chronic kidney disease patients. J Hum Nutr Diet. 2011;24:86-95.

22. Sheahan SL, Fields B. Sodium dietary restriction, knowledge, beliefs, and decision-making behavior of older females. J Am Acad Nurse Pract. 2008;20:217-24. 